\title{
Engaging truthiness and obfuscation in a political ecology analysis of a protest against the Pengzhou Petroleum Refinery
}

\author{
Edwin A. Schmitt ${ }^{1}$ \\ Hongtao Li \\ Center for Advanced Study and University of Oslo, Norway \\ Center for Advanced Study, Norway and Zhejiang University, PRC
}

\begin{abstract}
This article draws from an empirical case study of the use of truthiness and obfuscation during an environmental protest in China, to help highlight the complex issues that political ecology faces in the Post-Truth Era. By drawing on empirical data from social media and local interviews, this article documents rising social tensions associated with air pollution and the recent construction of a petroleum refinery outside of Chengdu. The article notes how historical precedent and the obfuscating of environmental information by government officials provided the conditions that led to residents presenting a selection of facts or even false information to support truth-claims that in turn supported their protest against the refinery. While this tactic of using truthiness to support an environmental protest may have sent the relevant information viral across the internet, the article also documents how the Chinese state in the end was able to de-legitimize the protestors by labeling their behavior as "anti-science." The article draws on this case study to encourage political ecologists to critically evaluate and contextualize the limits of utilizing alternative facts to challenge authoritarian control over the environment.
\end{abstract}

Key words: Post-Truth, environmental protest, social media, China, environmentality, necropolitics

\section{Résumé}

Cet article s'inspire d'une étude de cas empirique sur l'utilisation de la vérité et de l'obscurcissement lors d'une manifestation environnementale en Chine. L'article aide à décrire certaines des questions complexes auxquelles l'écologie politique est confrontée dans "l'ère post-vérité." En s'appuyant sur des données empiriques tirées de médias sociaux et d'interviews locales, cet article documente les tensions sociales croissantes liées à la pollution de l'air et à la construction récente d'une raffinerie de pétrole en dehors de Chengdu. L'article souligne comment les précédents historiques et l'obscurcissement des informations environnementales par les autorités gouvernementales ont fourni les conditions qui ont amené les habitants à présenter une sélection de faits ou même de fausses informations à l'appui des affirmations de vérité qui ont soutenu leur protestation contre la raffinerie. Cette tactique consistant à utiliser la vérité pour soutenir une manifestation environnementale a envoyé des informations virales pertinentes sur Internet, et l'article explique également comment l'État chinois a finalement été en mesure de délégitimer les manifestants en qualifiant leur comportement de "anti-science." L'article s'appuie sur cette étude de cas pour encourager les écologistes politiques à évaluer de manière critique et à contextualiser les limites de l'utilisation de faits alternatifs pour contester le contrôle autoritaire sur l'environnement.

Mots-clés: post-vérité, protestation environnementale, médias sociaux, Chine, environnementalité, nécropolitique

\footnotetext{
${ }^{1}$ Dr. Edwin A. Schmitt, Center for Advanced Study and University of Oslo, Norway. Email: schmitte "at" link.cuhk.edu.hk. Dr. Hongtao Li, Professor, College of Media and International Culture, Zhejiang University, Hangzhou City, Zhejiang Province, PRC and Center for Advanced Study, Norway. We would like to thank the Center for Advanced Study, Oslo, Norway for hosting us and providing us with the perfect scholarly atmosphere that gave birth to this collaboration. We thank everyone on the Airborne project, but particularly Mette Halskov Hansen who provided feedback on an earlier draft. We also thank Joseph Bosco for a critical read of that initial draft as well as important comments from two anonymous reviewers.
} 


\section{Resumen}

Este artículo se basa en un estudio empírico de caso del uso de la verdad y la confusión durante una protesta en China. El objetivo es ayudar a destacar los temas complejos que la ecología política enfrenta en la era de la posverdad. Con base en datos empíricos de redes sociales y entrevistas locales, este artículo documenta las crecientes tensiones sociales asociadas con la contaminación del aire y la reciente construcción de una refinería petrolera a las afueras de Chengdu. El artículo señala cómo los precedentes y la información confusa suministrada por oficiales del gobierno, establecieron condiciones para que los residentes presentarán una selección de datos, e incluso, información falsa para sustentar afirmaciones de verdad con las que respaldaron sus protestas contra la refinería. Mientras que esta táctica de usar la verdad para sustentar una protesta ambiental puede proyectar información relevante de manera viral por Internet, el artículo también documenta cómo el estado Chino al final, fue capaz de restar legitimidad a los manifestantes, al etiquetar su comportamiento como "anti-ciencia". El artículo se basa en este caso de estudio para alentar a los estudiosos de la ecología política a evaluar críticamente y contextualizar los límites del uso de datos alternativos para desafiar el control autoritario del medio ambiente.

Palabras clave: posverdad, protesta ambiental, redes sociales, China, ambientalidad, necropolítica

\section{Introduction}

Throughout early December 2016, Chengdu, the capital of Sichuan Province in western China, was shrouded in a blanket of choking smog. Local citizens flooded Chinese social media platforms like Weibo and WeChat Moments with pictures of "severe smog" and angry messages. One of the most widely shared messages included the following remarks that were allegedly made by the famous Chinese TV anchor Bai Yansong:

Having lived in many cities in my life, I have never seen any of them fall from having a flawless reputation to one suffering from grievances rising from all directions... it will not take long before this city will gradually recede from view... the only thing remaining would be a tattered and polluted urban ruin. A group of simple and ignorant people, a city haunted by cancer: This city is called Chengdu. ${ }^{2}$

As the remarks were reportedly not written by the anchor himself, the state subsequently censored social media posts that used the quote. The wide circulation of the remarks does, however, represent one way residents were able to express their discontent with the environmental disaster on their doorstep, regardless of whether the comments were actually written by Bai Yansong or not. In this article, we contend that the sharing of "alternative facts" constitutes a discursive strategy used by citizens because they believe such language and imagery is beneficial to their protest against a petroleum refinery and air pollution in China. Political ecologists have long demonstrated how "alternative facts", or knowledge that does not fit the standard scientific model, can have a liberating power, particularly for indigenous groups (Sullivan 2017). Because the creation of "scientific facts" and "alternative facts" are always a process of social negotiation, it is advisable that we reflect on the positive and negative impacts they have on society. Currently, political ecologists are re-assessing productive ways to both work with science and critique its hegemonic claim to truth over other ways of understanding the environment (Neimark et al. 2019). As we will see in the end, there may be limits to the utilization of "alternative facts" that can create an unproductive tension between environmental protesters and authoritarian regimes. Following the current rise of populist authoritarian movements, it is now necessary to critically analyze illiberal means of governing the environment (Sonnenfeld and Taylor 2018) and gain greater insight from political ecologists studying regions of the world that are or were governed by authoritarianism (i.e. Harper 2005; Vesalon and Cretan 2015). The way discursive regimes ensure that only some "facts" are allowed to circulate among the public is made more explicit within authoritarian political structures, but we follow Hurst (2017) in arguing that in some cases what we learn in China can have relevance for many current situations around the world.

\footnotetext{
2 http://bbs.tianya.cn/post-travel-793616-1.shtml
} 
Over a decade ago, Ralph Keyes provided a name for this new historical period: The Post-Truth Era. Keyes (2004:11) argues that "we may be no more prone to making things up than our ancestors were, but we are better able to get away with deceiving others, more likely to be let off the hook if exposed, and in the process convince ourselves that no harm's been done." Keyes' final point regarding this ability to convince ourselves that there is little harm in spreading lies has also allowed for the popularization of the idea of "truthiness" or "the belief in what you feel to be true rather than what the facts will support." ${ }^{3}$ While truthiness is well known as a satirical device used to critique those in positions of power, it has also been used to reflect on a general social condition (Anderson 2017) and highlights the similar agency available to any individual when presenting truth-claims. In this article we operationalize truthiness as the presentation of "facts" by individuals or even entire social groups to support the claims that they feel to be true. While China has dealt with the phenomena of truthiness for decades, in this article we intend to systematically examine how it is used and for what reason. The spreading of the statement supposedly made by Bai Yansong is a good example of truthiness because when residents of Chengdu were confronted by the fact that it was not written by Bai Yansong a common reply that we heard was "that doesn't matter because [the statement] accurately represents what I believe Chengdu will become in the future." As we will see, what Chengdu residents claim to be true about air pollution, regardless of whether or not that claim can be verified, is expressed in a variety of ways.

Typically, academic literature has critically analyzed the Post-Truth Era by focusing on the way social elites and the state are able to instigate social polarization (Munger 2008) by obfuscating the scientific information that could be used to help us understand and debate environmental issues, such as climate change (Nisbet 2016). Here we operationalize the concept of obfuscation as an action taken to prevent access to the "facts." In contrast to some current populist movements that support authoritarianism around the world, China has never been "anti-science" per se. Instead, scientific research has always been regarded as first and foremost instrumental to achieving the political goals of an authoritarian regime (Brombal 2017). Some might argue that the kind of environmental authoritarianism found in China (Beeson 2010) explains why the Chinese state tends to obfuscate information about air pollution (Andrews 2008).

With this article we demonstrate how the Chinese state obfuscated environmental information surrounding China National Petroleum Corporation's (CNPC) construction and management of the Pengzhou petroleum refinery. Examining the obfuscation of this information is crucial for understanding why environmental protestors decided to engage in truthiness to support their cause. We will show that it is precisely due to the lack of government transparency surrounding the Pengzhou petroleum refinery, located $30 \mathrm{~km}$ north of the city of Chengdu, that residents were able to shift the blame for persistent levels of air pollution towards the refinery. This was despite the fact that scientific studies showing automobiles to be the greater contributor to the city's air pollution were widely shared at that time (see Shi 2016). Specifically, we will address the following questions:

- How was the practice of truthiness by residents of Chengdu shaped by the state's obfuscation of environmental information?

- To what extent did citizens engage with truthiness to express their discontent with air pollution and what implications did such an engagement have for local environmental activism?

Answers to these questions will contribute to a better understanding of the dynamics of negotiation between citizens and authorities in environmental protests in China and beyond. This article will help the field of political ecology reflect on the potentialities and pitfalls that can exist for a social movement that attempts to draw on truthiness to support their resistance to authoritarian control over environmental information.

\footnotetext{
${ }^{3}$ This is the correct definition provided by Stephen Colbert, who famously satirized this word in 2005; see Language Log (2005) for a thorough etymology. Many sources misquote Colbert by saying that the definition of truthiness is: "The quality of stating concepts or facts one wishes or believes to be true, rather than concepts or facts known to be true" (See Munger 2008). Colbert reconfirmed his definition of truthiness and provided his take on the concept of Post-Truth on the November $18^{\text {th }} 2016$ edition of The Late Show with Stephen Colbert.
} 


\section{Social power in a post-truth era of environmental politics}

The field of Political Ecology has long argued that our understanding of the interaction between the human and non-human world is never perfectly clear, and that the hegemonic form of truth-making found in modern science can often drown out indigenous ways of understanding our environment (Robbins 2011; Sullivan 2017). Certain Chinese worldviews, for instance, have provided residents with important sources of meaning when they are coping with the adverse health effects of perceived environmental pollution (LoraWainwright 2013). However, the contentiousness of the Pengzhou petroleum refinery did not directly intersect with Chinese indigenous knowledge systems. Thus, our examination of this case focuses on the way scientific truth-claims are debated in China.

Typically, the rise of post-truth politics provides populist movements with an anti-science ideological frame that primarily serves to reproduce authoritarian power structures in society. This creates a paradox for political ecologists who often provide a voice for other ways of understanding the environment. Today, we must ask "how can political ecologists... work with science to show that the form of critical engagement we advocate and practice is different from those propounded by the authoritarian right?" (Neimark et al. 2019: 614). Some fruitful discussion has developed regarding the integration of environmental science and political ecology perspectives (Turner and Robbins 2008) and there are even examples of the way that ecological knowledge can productively span across collaborations between indigenous communities and scientific researchers (Rival 2014).

Political ecology is properly equipped to lend its critical lens to the way state actors may draw on the hegemony of science to support their interpretation of a contentious environmental issue, by critiquing discourses of what Fletcher has described as sovereign, disciplinary, neoliberal and truth environmentalities (2017). Extending Yeh's (2009) critique of the neoliberal environmentality found in the discourse of payment for ecosystem services in rural grassland and forested mountain communities of West China, Zhang (2018) has demonstrated how the Chinese state utilized a sovereign environmentality to protect the grasslands and reduce the intensity of sandstorms by making Mongolian pastoralists accept a more sedentary life. Political ecology has also flipped analyses of Foucaultian biopower to ask who gets to inflict industrial pollution on a given population (Davies 2018), and how do residents cope when they remain within these "sacrifice zones" (Little 2017), leading to new critical examinations of necropolitics (Cavanagh 2018; Mbembé and Meintjes 2003). In this article we will primarily examine the sovereign and truth environmentalities related to contention over who has the power to say that air pollution derives from a given source, and who determines whether or not a truthclaim about air pollution is valid. Political ecologists in China have demonstrated how rural communities in China both actively and passively come to resist the industrial pollution in their lives (Lora-Wainwright 2017; Tilt 2010). Much of the political ecology of China (Yeh 2015) has tended to focus on rural communities, and more urban case studies are needed (Heynen 2014). Our study also highlights the way urban residents in China have drawn on social media to support environmental protests (Yang 2010). Some political ecologists have similarly drawn on social movement studies to demonstrate the way social media provides new kinds of agency to activists within environmental protests (Matulis and Moyer 2018). This article aims to integrate a rich literature of social protests in China (Lorentzen 2017) with a critical analysis of urban environmental discourse to evaluate the complex problem that truth-claims by state actors and environmental protesters present for political ecology.

We argue that some of the complexity in this problem arises from how human understanding of the environment is presented. Environmental scientists drawing on a system of logic for interpreting random phenomena tend to focus on environmental uncertainty (Functowicz and Ravetz 1990). Uncertainty is the unknown about the environment, which we endeavor to learn more about. However, the focus of our current analysis is on the obfuscation of environmental knowledge. As we will see, it is possible that state actors can obfuscate information about the environment by engaging in two kinds of actions. First, an institution can restrict resources and funding for certain research topics, thereby preventing scientists from publishing results for public scrutiny. ${ }^{4}$ Second, state-controlled media can choose to not publicize information that is already

\footnotetext{
${ }^{4}$ See Banchoff (2005) for an example of how this played out globally with regard to stem cell research.
} 
known to the scientific community. ${ }^{5}$ In China, the state often plays a central role in preventing certain research topics from being studied or the public from learning about known scientific facts (Brombal 2017). It is a familiar refrain that Chinese science is tainted by political ideology and propaganda, which could be true but it is still important to explore that relationship in specific instances (Schmalzer 2007). Critically examining practices of obfuscating environmental information helps us to contextualize the way environmental protestors engage with truthiness.

The way people or groups use truthiness to discuss the environment's impact on humanity (or vice versa) can also be seen through two processes. First, only facts that support a given truth-claim are presented and often this is done under the pretense that all information was shared. ${ }^{6}$ Second, false information may be presented as factual, to support a given truth-claim. It is possible that both state and non-state actors can mobilize these two kinds of truthiness. Table 1 helps organize the way we interpret obfuscation and truthiness as forms of intentional communication and the two kinds of actions that can be taken to transmit these forms of intentional communication in the Post-Truth Era. By 'intentional communication' we mean to say that these speech acts performed by individuals, groups or state entities included "an understanding of the role of Others in our perception, thoughts, feelings, evaluations, and actions" (Duranti 2015: 238) in order to build public support for their truth-claim within their community. We should also note that while obfuscation and truthiness are typically used to prevent the public from learning information about the severity of environmental risk, truthiness can also be used to exaggerate the situation and, as our case study will show, to critique the state's obfuscation of environmental information. It is at the intersection of social power and our understanding of the environment that we can gain a better insight into this relationship between the obfuscation of environmental information and how it relates to the way individuals may or may not engage with truthiness.

\begin{tabular}{|c|c|c|c|}
\hline & Form & Operationalization & Action \\
\hline \multirow{4}{*}{ Post-Truth } & \multirow{2}{*}{ Obfuscation } & \multirow{2}{*}{$\begin{array}{l}\text { An action taken to prevent } \\
\text { access to the facts }\end{array}$} & $\begin{array}{l}\text { Preventing facts from being } \\
\text { researched }\end{array}$ \\
\hline & & & $\begin{array}{l}\text { Preventing others from knowing } \\
\text { about known facts }\end{array}$ \\
\hline & \multirow{2}{*}{ Truthiness } & \multirow{2}{*}{$\begin{array}{l}\text { The presentation of "facts" by } \\
\text { individuals or even entire } \\
\text { social groups to support the } \\
\text { claims that they feel to be true }\end{array}$} & $\begin{array}{l}\text { Presenting only selected facts that } \\
\text { support a given truth-claim }\end{array}$ \\
\hline & & & $\begin{array}{l}\text { Presenting false information as } \\
\text { fact to support a given truth-claim }\end{array}$ \\
\hline
\end{tabular}

Table 1: Obfuscation and Truthiness.

Social power is an important element to consider when trying to understand the way the public reacts to environmental information. While we need to be cautious about reifying state power (Abrams 1988), in China it is also important to realize that government officials practice governance in a manner that ensures state agencies remain the "sole carrier of legitimate power" (Pieke 2004: 518). These are the practices that reinforce the kind of sovereign environmentality discussed below, but the logic behind such practices are not always available for analysis. Rather than attempting to place a static definition upon the ever-shifting nature of Chinese state power, a more productive method is to provide a "sketch of one face [the state] shows when tests of its

${ }^{5}$ See Carvalho (2007) for an example of how ideology impacts the way media organizations report on climate change.

${ }^{6}$ See Sparks (2006) for a very relevant example of how a petroleum refinery used the presentation of half-truths to encourage people to be less concerned about localized pollution. 
tolerance arise" (Stern and O'Brien 2012: 175). This is why we have chosen an analysis of the use of obfuscation and truthiness during an environmental protest about the Pengzhou petroleum refinery to provide an important case study for the evaluation of how political ecologists might engage with the complexities of truth-claims within an authoritarian context. Thus, this article will also try to be explicit in its analysis of government practices (Adams 1988), rather than assuming the Chinese state to be a monolithic entity.

As we will show, the hegemonic power of Chinese officials can prevent the public from gaining access to environmental information. Moreover, state power can be reinforced when the government engages in forms of persuasion (Guha 1983), including discourses found in press conferences and official media articles, that attempt to make the public accept that the environmental risks to their health caused by industrial production are minimal. As we will see, officials often obfuscate the way petroleum is refined and the contribution these refineries make to the production of smog. The public in turn also engages in various forms of resistance that aim to counteract the obfuscation of environmental information by demanding greater transparency from environmental protection agencies. Sometimes in China when the public is denied environmental information about a development project that will impact their community, they can enlist the assistance of NGOs (Sun, Huang and Yip 2017) or experts (Johnson 2013), who Mertha (2008) describes as 'policy entrepreneurs', to support their protest against the government's support for such a project. For reasons we will explore below, some behaviors, such as engaging in truthiness, may make NGOs or experts less inclined to support such protests.

During the 1990s in China, modes of collective resistance were often small in size, the grievances were exclusive to specific groups, protests were held ex post facto and there was little interest in attempting to affect policy (Cai 2010; O'Brien and Li 2006; Yang 2005). However, we follow Steinhardt and Wu (2016) in arguing that a new repertoire of widespread protests has emerged that is inclusive of the public's desire to force the state to take preventative action against polluters. ${ }^{7}$ Moreover, as we demonstrate, while protestors in the previous repertoire often required the support of the media to ensure the success of their movement (Tilt 2010:114-120), today we see protestors often defining what the media will write about due to the prevalence of social networking tools like WeChat and Weibo. In some instances, residents could even place government officials in situations where they know the institutions behind those officials will fail to uphold certain promises, such as providing clean air, and then use that failure to draw greater attention to their movement through the media (Distelhorst 2017). However, in extreme cases, such as those discussed below, the state will shut down all forms of media that might support a protest (See also King, Pan and Roberts 2013) and are able to de-legitimize the movement when protestors utilize truthiness to support their cause. While other scholars have noted the opportunistic use of mis-framing by organizers of Chinese environmental protestors (Deng and Benney 2017) ${ }^{8}$, with this case study we are specifically focused on the interaction of truthiness used by both government actors and citizen protestors and what this means for power relations between these two groups. We will show how the obfuscating of environmental information associated with petroleum refining by the state has produced a grey area between official and civil discourse, which provides a space for the operation of truthiness. Finally, the article has implications for how political ecology can "clarify the mechanisms of knowledge production and exclusion" (Neimark et al. 2019: 4) at the center of contentious environmental politics, while also forcing us to reflect on the limitations "alternative facts" might create for protestors in the face of authoritarianism.

In the following sections, we will first introduce the debate about the dangers of petroleum refining as it relates to environmental issues in Chengdu and in particular to air pollution. This will provide background information but also allow us to develop concepts important to our analysis of truthiness that follows. Since December 2013, one of us has been conducting a long-term on-going ethnographic study of environmental issues in Chengdu, including direct interviews and multiple follow-ups related to the Pengzhou petroleum refinery case with five officials responsible for environmental protection in Sichuan, three journalists, four local

\footnotetext{
${ }^{7}$ For other studies that have also demonstrated this shift in the way resistance is enacted in China see Deng and Yang (2013), Johnson (2013, 2016), Mertha (2008) and Wang (2008).

${ }^{8}$ Deng and Benney (2017) detail a case where local citizens latched onto a "fake political opportunity" (i.e. government officials changed the name of an industrial park to avoid the heavy hand of environmental regulators) to support their protest. The author's use of the word "fake" is quite misleading as in no way did citizens use false information or a selection of facts to support their protest.
} 
NGO organizers and 40 residents of Chengdu. As will become clear, protests against the refinery were a hybrid of online and offline activities. Online materials allowed us to stay directly connected to the event and draw from a wider range of perspectives (See also Simonelli 2014). Particularly, in December 2016 our informants provided us with media content that was circulating widely in the lead up to the protests discussed in Section 5. We drew from material that our informants in Chengdu posted to the publicly viewable WeChat Moments that often stimulated discussion about the use of truthiness to support the protest. We also conducted our own search of social media within WeChat Public Accounts and on Weibo, using keywords such as "Pengzhou refinery", "PX" (see Section 3), and smog ("wumai" in Chinese). These searches led us to public discussions on social media and online content from China's state-media agencies. Some of the media content described below is representative of the material collected from these searches. Thus, our analysis of the protest draws from online social media posts, media reports, government documents as well as interviews with officials, journalists, NGO leaders and local residents to help frame our argument.

\section{A debate about the dangers of petroleum refining and PX production}

The way social protests against air pollution become connected with specific industrial sites is not always so direct. Chengdu residents' concern for air pollution became tied to the recent controversial construction of a petroleum refinery complex in Pengzhou, a city on the North edge of the Chengdu Plain, only after years of contention. Initially, most residents critical of the refinery tended to focus on the production of the toxic chemical paraxylene, ${ }^{9}$ or PX, a chemical used in the production of polyethylene terephthalate to make fabrics, plastic bottles and other synthetic materials. PX has a high boiling point $\left(138.35{ }^{\circ} \mathrm{C}\right)$ meaning that it will not evaporate during a spill, increasing the chance that it could leach into the water system if the proper environmental protocols are not followed, a concern that many Chengdu residents worry about when they discuss the refinery in Pengzhou. A more direct concern is the various compounds of air pollutants produced at the refinery including, benzene and particulate matter. Over the past decade, China has seen a number of PX protests, including the long-term dispute over the construction of the Pengzhou refinery that we discuss in this article. $^{10}$

How the government has reacted to public concern over the environmental pollution coming from the Pengzhou refinery is closely connected to the national-level debate over the production of PX. To assuage these concerns, Chinese state media has attempted to improve the petroleum industry's reputation for environmental safety. For instance, one article from China Energy News (Zhang 2014), written primarily through the voice of a government expert, Professor Cao Xianghong, stated that a key challenge for the petroleum industry is dealing with the social fear of PX. To explain the level of danger found in PX production Professor Cao, who was the chief engineer for the state-owned Sinopec Corporation, used the following simile to explain his thinking to the reporter:

PX projects are like a zoo, where dangerous animals are locked up in cages. Such as it is, the zoo still poses a danger to children and yet they have become a playground for children...During the production process of PX, not only can we control for risks to safety, but when compared to the production of other chemicals, on the contrary the risk is much smaller.

In this quote, we can see Professor Cao presenting a rhetorical metaphor along with a statement about the ability to control safety risks associated with PX production. Taken together he intends this claim to be interpreted as if it was a fact, saying that PX production is as safe as a day at a zoo, thereby supporting the belief that PX production is not dangerous to the surrounding community. By equating PX production with a zoo, Professor Cao is attempting to speak to the concern many residents of Chengdu feel for the health and safety of their children in relation to the refinery directly upstream of the city. In other words, he is trying to persuade his

\footnotetext{
${ }^{9}$ For a toxicity assessment of p-Xylene see http://www.cdc.gov/niosh/idlh/95476.html

${ }^{10}$ For a list of these protests see http://www.scmp.com/topics/paraxylene-px. See also Liu (2016), Liu et al. (2016) and Steinhardt and $\mathrm{Wu}(2016)$.
} 
readers that while the Pengzhou refinery is indeed upstream of Chengdu, the danger it poses to one's children is no greater than a day at the zoo. Of course, this conflates a crucial difference in that we generally do not bring our children to the zoo every day, and once the refinery begins operation there is a chance that an accident could occur at any moment. He also does not clarify which other chemical production processes he is referring to when saying that the risk posed by the production of PX is relatively small. With this example, we can see the persuasive power of the state relies on having experts present only the facts that support the required truthclaim: that the environmental risks from PX production are minimal. This also shows how the state-run media utilizes everyday discourse to reconstruct a sovereign environmentality that delineates who is and who is not being poisoned by environmental pollution.

We can also see the way citizens use truthiness in separate incident related to the production of PX. In late March 2014, the residents of Maoming City in Guangzhou Province began a citywide protest over the construction of a nearby refinery leading to the arrest of 18 residents by riot police (Anonymous 2014). On April 1st, pictures of tanks and military units being sent to Maoming paired with the words "15 dead, 300 wounded" were distributed on social media. The intention of sharing this post was to make others feel that PX must be dangerous, otherwise why would the government be killing protestors? Further research has shown that the unrest did not result in deaths or the use of military intervention, but rather drew on the experience of previous PX protests around China (Zhu 2017). However, we want to draw attention to protestor's use of false information (to support their claim that the PX plant in Maoming is dangerous and therefore in need of mobilizing resistance). Citizens can also manipulate a truth environmentality regarding what kinds of environmental information is or is not worthy of generating social protest. Protestors in China also use truthiness to drum-up support for their cause. The use of false pictures of military suppression in Maoming is just one example. ${ }^{11}$

Although design of the Pengzhou refinery began in the 1980s, it was in 2008 that many residents of Chengdu suddenly became aware that the government was about to break ground on the project. One of us attended the first organized protest against the refinery in early May 2008, when a group of no more than a hundred Chengdu residents marched just outside Sichuan University but were prevented from entering downtown by hundreds of military police (See also Wong 2008). At the time, protestors were concerned that environmental impact assessments (EIAs) had demonstrated that the siting of the refinery alongside the Tuo River posed a potential risk to millions of residents living in downstream communities of Chengdu. ${ }^{12}$ According to one media report, the refinery would annually refine 10 million tons of oil, 800 thousand tons of ethylene, and a range of other chemical precursors (Liu 2014). The plant would supposedly also produce 600 thousand tons of PX per year (See comments to Yin Nan 2013). Official accounts of the chemicals produced at the refinery in Pengzhou are not released to the public and most references in the media are continuously deleted by state censors. EIAs conducted before operation began determined that the refinery would produce a number of pollutants that would contribute to the already worsening air quality in the Chengdu Plain (Shu 2012: 172173). Officials in the Chengdu Environmental Protection Agency (EPA) argued that the local environment did not have the capacity to safely absorb the level of pollution emitted from the plant. However, because this was a national-level project sponsored by the politically powerful China National Petroleum Corporation (CNPC) and included a 300 billion RMB [US\$43 billion] investment package, the EIAs and the concerns of the local officials were not enough to stop the political momentum that moved the project forward (Liu 2014). Wang Wenbin, then the head of the Chengdu EPA, supposedly developed a 900 million RMB [US\$129 million] budget proposal that intended to monitor every aspect of the refinery's production process. After years of negotiations with relevant Finance Departments he was only able to secure 200 million RMB [US\$29 million] worth of monitoring equipment. Many environmentalists in Chengdu believe his early death in 2013 was due to the stress of trying to protect Chengdu from the environmental risk posed by the Pengzhou refinery. Before the protests began in December 2016, informants within the Chengdu EPA told one of us that because resources

\footnotetext{
${ }^{11}$ A similar precedent related to the presentation of half-truths could also be seen in the Xiamen protests in 2007 when an SMS message spread around the city for months that the construction of the PX plant in Haicang District would be like "setting off an atomic bomb in all of Xiamen" (Cody 2007).

${ }^{12}$ On the contentious politics involved in the siting of petrochemical plants in China see Gu (2016).
} 
were not properly allocated, their agency was still unable to install proper monitoring equipment to determine the extent to which the refinery contributed to the worsening air quality in Chengdu. ${ }^{13}$ Preventing proper research about the Pengzhou refinery emissions is an example of state actors obfuscating environmental information.

The refining of petroleum is indeed a complex process that "requires a sophisticated, multidimensional, and time-varying formulation that links operating variables, product specifications, input and output prices, and environmental and economic constraints" (Gary, Handwerk and Kaiser 2007: 20). However, a major element too often missing from this equation is the willingness of local residents to live with the levels of pollution emitted from the factory. Residents of Chengdu that we interviewed felt that ultimately decisions related to the refinery were compartmentalized among a small group of experts. Timothy Mitchell (2011) argues that it is precisely the technical nature of the petroleum industry that has prevented any organized public resistance to its ability to manipulate political power. The management of the Pengzhou refinery has been able to orient a sovereign environmentality that allowed them to demand the refinery's construction in this specific location and obfuscate any environmental information about its operations from being disseminated to the public.

\section{Building tensions over air pollution}

As mentioned above, making a connection between the Pengzhou refinery and air pollution was a gradual process, up until 2015-2016 (see Figure 1). In the following section, we provide context for how this connection was made in the months preceding the December 2016 protests. The initial event that linked the refinery and air pollution for a small group of residents began on July $22^{\text {nd }}$, 2015, when an accident occurred at the Pengzhou refinery. While the media decided not to report on the accident that day, by the following morning of July $23^{\text {rd }}$, a number of videos had begun to circulate on social media. The videos showed the refinery billowing black smoke that created a massive dark cloud in the sky floating towards Chengdu. ${ }^{14}$ Because it was obvious to viewers the accident had occurred the afternoon before and there were no media reports about the accident, this caused panic to spread throughout the city. As the local government struggled to contain the situation, there were initial attempts to blame the authors of the EIA that was conducted before the refinery was constructed. One official within the Chengdu EPA told one of us that there had never been support from the Provincial authorities for the construction of the project but rather that it was forced upon them by the Central Government.

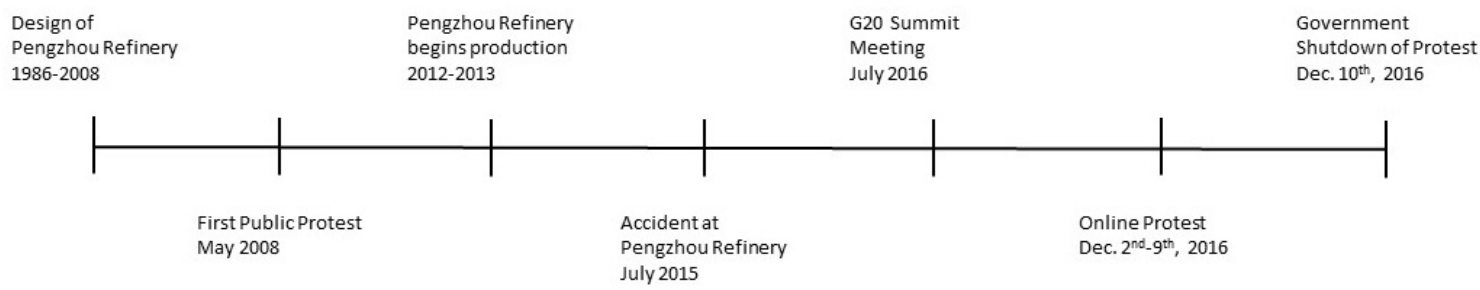

Figure 1: Timeline of events leading up to the protest.

\footnotetext{
${ }^{13}$ In July 2017, the head of the Sichuan Provincial EPA, Yu Huiwen, claimed newly installed monitoring devices and 21 drones were purchased to determine the amount of pollution coming from the Pengzhou refinery. He outlined the different types of emissions in precise detail and claimed them to be comparable to the emissions coming from a medium-sized coalfired power plant with $600 \mathrm{MW}$ of installed capacity (Xiang 2017).

${ }^{14}$ For a collection of these WeChat reports see: http://chinadigitaltimes.net/chinese/2015/07/\%e3\%80\%90\%e7\%bd\%91\%e7\%bb\%9c\%e6\%b0\%91\%е8\%ae\%ae\%е3\%80 \%91\%e8\%bf\%99\%e4\%b8\%8d\%e5\%8f\%ab\%e6\%b1\%a1\%e6\%9f\%93\%e5\%95\%a5\%e5\%ad\%90\%e5\%8f\%ab\%e6\%b1\% $\underline{\mathrm{a} 1 \% \mathrm{e} 6 \% 9 \mathrm{f} \% 93 /}$
} 
On the morning of July $24^{\text {th }}$, CNPC finally released a statement saying that it had taken two days to determine the exact cause of the black smoke, which amounted to electricity fluctuations disrupting machinery that allowed moisture to build up within one of the furnaces used in the distillation process. This prevented full combustion of the natural gas used in the furnace forcing the plant to expel dark smoke for nearly two hours. The plant was shut down for inspection but was quickly resumed activity. Only hours later China Electric came out with a statement saying that at no point did the electricity needed to properly run the Pengzhou refinery fluctuate and accused CNPC of giving a false statement in an attempt to sidestep responsibility for the accident. ${ }^{15}$ Thus, actors working for the state-owned CNPC had not only obfuscated the normal operations of the petroleum refinery, it appeared to Chengdu residents that CNPC had even presented false information to the public in order to minimize what appeared to be a serious accident. This event stimulated days of discussion about the dangers of the refinery among the city's environmental activists.

A year later, one event stands out as a definitive moment when the general public began to lay the primary blame for Chengdu's air pollution problem squarely on the Pengzhou refinery: the shutdown of industrial production during a G20 Summit meeting in July 2016. While the primary G20 event took place in the eastern city of Hangzhou, a preliminary meeting among the G20 finance ministers and central bank governors was arranged in Chengdu on July $23^{\text {rd }}-24^{\text {th }}$. During the days before the event, vehicle traffic in Chengdu was not restricted, but industrial factories were asked to close for a week. Throughout that week, air pollution levels remained quite low with pictures of blue skies trending heavily on social media by July $19^{\text {th }}$. The resulting social discourse led residents to believe that vehicle traffic was not as significant a contribution to smog in Chengdu as had previously been argued by the government, scientists and environmental NGOs (See Shi 2016). The alternative source of air pollution, local residents came to believe, was the Pengzhou refinery. By the time the first Air Quality Orange Alert was declared in early December, tensions in the city were already running very high. These guided some of the initial uses of truthiness to support online and offline protests against the Pengzhou refinery and Chengdu's air pollution levels, discussed in the following section.

Two aspects of this important context contributed to the way truthiness became a discursive strategy for a local environmental movement. First, the relationship between air pollution and the refinery grew public discontent over time, and once any discursive opportunity related to these issues emerged it attracted a great deal of public attention. Second, that the degree to which officials at CNPC had obfuscated the operation of the refinery had created a discursive space allowing residents to make claims that were unverifiable or even false, but at the same time fitting a socially accepted narrative. In the following sections, we will see more clearly how these conditions led to the use of truthiness in an online and offline protest of the Pengzhou refinery's supposed contribution to a severe pollution episode in Chengdu in December 2016.

\section{Engaging with truthiness on social media}

On December $2^{\text {nd }}$, 2016, highly contested information began circulating that Chengdu had the third worst air quality level in the world. This argument was based on a screenshot of an APP ${ }^{16}$ that included data from 8,000 air monitors in a limited number of cities around the globe (Wangong Shuweng 2016). On that day Chengdu just happened to be exhibiting the third highest level, on this incomplete database. By December $5^{\text {th }}$, the Chengdu EPA in tandem with local media began to issue reports that this report was biased and had only drawn on data from a very small sample of cities that did not even include many cities in China with far worse levels of air pollution (CDEPA 2016). Although the Chengdu EPA demonstrated that the ranking was inaccurate, people continued to post screenshots from the APP and criticized the government for missing the point. One local writer (Nie Zuoping 2016), for instance, pointed out in a widely circulated WeChat blog post that it was odd for the authorities to dispel the message as inaccurate, because regardless of whether Chengdu was ranked as the third or the thirtieth in the world, the only thing that mattered was the shockingly high levels of air

\footnotetext{
${ }^{15}$ For details about the debate between CNPC and China Electric see: http://chinadigitaltimes.net/chinese/2015/07/\%e5\%bd\%ad\%e5\%b7\%9e\%e7\%9f\%b3\%e5\%8c\%96\%e5\%86\%92\%e9\%bb \%91\%e7\%83\%9f\%e5\%90\%8e\%e7\%bb\%ad\%ef\%bc\%9a\%e6\%88\%90\%e9\%83\%bd\%e4\%be\%9b\%e7\%94\%b5\%e5\%90 \%a6\%е8\%ае\%а4\%е6\%9b\%be\%е5\%8f\%91\%е7\%94\%9f\%е7\%аa\%81\%е7\%84\%b6/

${ }^{16}$ See https://airvisual.com/
} 
pollution. Here we can see an example of how residents react when they are confronted with the fact that the information they are sharing is unverifiable or even false. In many cases residents become defensive or try to shift the focus of their reason for sharing such information away from its degree of veracity.

During this time, the general public also began to lay the primary blame for Chengdu's air pollution problem squarely on the Pengzhou refinery. As a result of the government's obfuscation of environmental information related to the refinery, people used different strategies to mobilize different truth-claims that did not necessarily draw upon verifiable information. The first strategy was juxtaposition by "calling out" the official Weibo account of Pengzhou refinery (@四川彭州石化基地) and using hashtags related to air pollution. For instance, online posts would simply assume or imply that Pengzhou refinery is the major contributor to Chengdu's poor air quality. Here is an example from the account of Zegehhh:

\author{
During the Great Era of Smog \\ Chengdu took the lead \\ Ranked third in the world \\ @Sichuan Pengzhou Refinery Base (Dec. 4, 2016) $)^{17}$
}

For these residents of Chengdu it was not necessary to have scientific evidence that the Pengzhou refinery is a major contributor to the air pollution problem because such a truth-claim already fits their understanding of the situation. In a relatively short period of time beginning on December $4^{\text {th }}$, hundreds of Weibo users utilized these methods to "call out" the Pengzhou refinery. Such a discursive move not only connected Pengzhou with the air pollution problem, but allowed the users to express their strong dissatisfaction with the refinery, as the digital function of the @ symbol created a sense of direct conversation with the company. In many posts, people fiercely criticized, attacked and even cursed the refinery. Similarly, the juxtaposition of hashtags \#Chengdu smog\# and \#Pengzhou refinery\# also implies the causal relationship between these two, while emotion-laden hashtags like \#Pengzhou refinery get out of Sichuan\# conveyed more clear messages of protest and the potential for collective action. More importantly, the use of hashtags aimed to attract more public attention to these issues by moving these keywords up onto Sina Weibo's "hot topics list."

The second strategy residents used to place blame upon the Pengzhou refinery for the problem of air pollution comes from personal observations. The best example of this emerges from the aftermath of the blue sky days that were seen during the G20 talks mentioned above. On December $3^{\text {rd }}$, the official Weibo account of Pengzhou refinery shared a news story demonstrating that over the past ten months, the air quality in Pengzhou city was actually much better than air quality in the center of Chengdu. This meant the problem could not be isolated to the Pengzhou refinery (Liao 2016). Here we can see the city government utilizing air pollution data only they have access to, along with persuasive means, to shift the blame for the problem away from the refinery. One comment below the posting of this news article, which received more than 1,900 likes, stated: "Let me ask you a simple question: did you shut down during G20?" The resident used this rhetorical question to say that their own interpretation of Pengzhou refinery's contribution to air pollution was informed by their personal observation of clean air during the G20. This kind of personal observation based on individual experience was used to suggest that the pollution created by the industrial factories needed to receive greater scrutiny (e.g. Wang 2016). It should be noted, however, that a lack of transparent and direct monitoring of the Pengzhou refinery's emissions by the Chengdu EPA ensured that there was no way to dispute the validity of these personal observations.

\title{
6. A post-truth protest and de-legitimization by the state
}

By drawing on truthiness found within digital juxtaposition and personal observations, residents were slowly building an online environmental protest. In the following section we will outline the key events that allowed the protest to also continue offline and then demonstrate how the use of truthiness by protestors provided government officials with effective "justification" for de-legitimizing the protests by labeling them as

${ }^{17}$ http://www.weibo.com/u/2342914794 
anti-science. On December $8^{\text {th }}$, 2016, examples of explicit discursive resistance began to appear throughout social networking sites like Weibo and WeChat. For instance, there were pictures showing facemasks wrapped around statues in central parts of the city, including a large mask wrapped around the face of the iconic Panda statue on the $7^{\text {th }}$ floor of International Financial Square (IFS). ${ }^{18}$ Other pictures showed residents wearing facemasks often standing on the balcony of a high rise building and holding a sign that provided their name or online handle, their location in the city and the slogan "I love Chengdu, please allow me to breathe" (Bestwise 2016). Another set of pictures included a piece of paper placed inside a plastic folder to prevent damage from the rain with a gas mask in the center surrounded by the slogans "Calling on the government to take care of smog. Give Chengdu back its clean air. Give Chengdu back its clean water." Interviewees informed one of us that relating the slogan to clean air and water was a way of drawing attention to the refinery without using the city name Pengzhou or PX, which are sensitive words that could result in a protest being shut down before it is able to gain the attention of other residents. The plastic folder was then attached to a resident's backpack and pictures were taken of them walking down the street or in their office. The idea was to encourage others to follow suit so as to take the discursive protest offline and into the streets. Later that evening a group of a dozen young women standing in front of the main entrance to Chengdu's IFS holding copies of these slogans were photographed, and widely circulated through WeChat accounts (Baba Zhongwan 2016). We should note that in contrast to the PX protests in the southwestern Chinese city of Kunming (See Sun, Huang and Yip 2017) these activities were organized completely independently without any input from an NGO.

These events emerged over the course of a week of high levels of air pollution and increasingly critical information about the government's mismanagement of the problem that was circulating on social media. On December $8^{\text {th }}$ and $9^{\text {th }}$ a small group of residents in Chengdu began to organize a protest march in the center of the city at Tianfu Square (Tang 2016). One set of promotional material meant to be distributed through WeChat showed a picture of a baby panda wearing a facemask with a single tear running down the mask. It included the following statement:

Chengdu Arise! Chengdu Hold On!

For the space you need to breathe!

For the city we love and live in!

For giving our children a blue sky!

If you agree with the above positions please circulate this!!

If you want to express your own ideas and desires, please wear your facemask and walk through

Tianfu Square at 10 a.m. on December 10th (Saturday). ${ }^{19}$

Similar to the protest slogans that were photographed in front of IFS, this material also avoided an explicit link with Pengzhou refinery for fear the censors would delete the material. Regardless, according to one journalist informant, not long after this promotional material appeared on WeChat, online censors also discovered it and raised an alarm within the state security apparatus.

It is possible to infer that the security apparatus was informed of the protest preparations, because the Chengdu Public Security Bureau took measures to prevent it from taking place at all (See Tang 2016). First, government agencies sent out a notice to all employees that they were not to take part in any public demonstrations in Tianfu Square during this period. For instance, one notice to all employees within the Sanitation and Family Planning Bureau of the city was distributed on December $9^{\text {th }}$ through WeChat saying:

All leading officials of various departments please inform your employees tomorrow (December $10^{\text {th }}$ ) they are strictly prohibited from participating in the protest march against Pengzhou refinery in Chengdu's Tianfu Square, participants will be strictly held accountable; particularly party members and leading cadres! Everyone please spread the word. ${ }^{20}$

\footnotetext{
${ }^{18}$ Facemasks on statues have become a common internet meme in China (Ji 2016). The IFS is one of Chengdu's largest shopping malls in the center of the city.

${ }^{19}$ A copy of this promotional material is on file with authors.

${ }^{20}$ A copy of this notice is on file with the authors.
} 
Then on the morning of December $10^{\text {th }}$ Tianfu Square was completely cordoned off from public traffic of any kind by large numbers of military police. Pedestrians were prevented from entering the square and car traffic was re-routed two blocks before even entering the square. Moreover, public buses and the subway were prevented from letting passengers on or off at the nearby stations. The police issued a news report claiming that the square had to be closed due to safety precautions related to Christmas (Sohu 2016). ${ }^{21}$

That afternoon pictures and short videos of protestors having signs and banners ripped from their hands by police began to circulate within various WeChat groups. Another picture of thousands of protestors supposedly marching against the Pengzhou refinery in Chengdu's Tianfu Square went viral across social media (Baba Zhongwan 2016). When residents who had originally intended on attending the protest discovered that Tianfu Square was sealed off by the police, they began circulating pictures of protests with captions that made it seem as if the city was demonstrating against the Pengzhou refinery. For nearly three hours this information was shared widely by residents from various backgrounds. Eventually, news agencies used social media to show that all of the pictures and videos that depicted widespread protest were from months or even years earlier. For instance, the picture of the protest in Tianfu Square actually occurred in 2012 when there was a mass protest against Japanese companies. However, when residents were confronted with this information, they often used it as further evidence of their angst. For instance, one resident made the comment "The borrowing of the picture is an expression of our dissatisfaction with smog! It is an internet protest!" Thus, we can see that protestors were utilizing truthiness with the intention to realign a truth environmentality in a way that would garner greater support for their resistance to the government's promotion of the refinery and inaction when it came to improving air quality. However, due to the hegemonic power held by officials supporting the Pengzhou refinery, this form of resistance was quickly suppressed.

The police and propaganda apparatus responded to the protest by shutting down any discussion of Pengzhou refinery and strictly limiting any discussion of air pollution. In response to this use of false information by protestors, the Sichuan Provincial government issued a notice that anyone who circulated this information on Weibo would be "prevented from posting for 15 days and prevented from being followed by others for 15 days" (Yu 2016). On December 10 $0^{\text {th }}$, reporters from party-controlled news agencies in Sichuan were invited to go with EPA officials to conduct snap inspections of the Pengzhou refinery. However, along with being told to only publish an approved text, media outlets were also issued the following warning:

Starting from today, all media outlets (including "branch papers" [子报] and new media), need to strictly control reports about winter smog and polluted atmospheric conditions. In such reports only use authoritative information from the Chengdu Environmental Protection Bureau, do not use your own interviews (including pictures) in your reports. ${ }^{22}$

Here we can see an explicit attempt by the state to ensure that only "authoritative information" about air pollution be distributed to the public. As one informant in the media explained, these strict measures were issued specifically to ensure that the government could counteract the spread of information used by the protestors and to label them as "anti-science." Although many in the Sichuan media community complained bitterly over these strict regulations, they were followed very carefully, resulting in articles about the environmentally friendly practices of the Pengzhou refinery (See Ding 2016). According to one NGO leader one of us interviewed, once these news reports emerged showing that the refinery was running according to the state defined environmental protection standards, people who continued to critique the refinery were then labeled as being "anti-science."

${ }^{21}$ There is a historical context behind this "safety precaution." In the early 2000s there was a tradition among Chengdu residents to congregate en masse at Tianfu Square during Christmas time. In 2003, inflatable plastic bats and hammers were sold on the street, which initially created a "playful" war like scenario where crowds of thousands would rush from one end of the square to attack another crowd at the other end. In some cases, the situation became physically violent (one of us was in attendance), multiple people were arrested and there was even a reported homicide (Sohu 2016).

${ }^{22}$ A copy of this notice is on file with the authors. See also

http://chinadigitaltimes.net/chinese/2016/12/\%E5\%9B\%9B\%E5\%B7\%9D\%E7\%9C\%81\%E5\%AE\%A3\%E4\%BC\%A0\% E9\%83\%A8\%E5\%85\%B3\%E4\%BA\%8E\%E6\%88\%90\%E9\%83\%BD\%E7\%8E\%AF\%E4\%BF\%9D\%E6\%8A\%A5\%E9 \%81\%93\%E7\%B4\%A7\%E6\%80\%A5\%Е9\%80\%9A\%E7\%9F\%A5/ 
Moreover, the authorities could now draw on the "fake protest" as evidence that a critique of the refinery was based primarily on falsehoods and misdirection. While NGOs recognized that a critical mass of protestors against Pengzhou had emerged during this period of time, once it became obvious that protestors were using false information to support their cause the NGOs were completely unwilling to associate with such activities because they were concerned that their organization would similarly be delegitimized as being anti-science.

The state also began to actively suppress any kind of resistance to the refinery or campaigns that connect it to the severe air pollution covering the city. Following the request of local police stations, neighborhood management committees sent out notices to all drug stores that they were not allowed to sell face masks to residents without taking down the customer's name and ID number. A similar requirement was issued to print and copy shops for customers wanting to print any material using words related to "bodily health, refinery project, Pengzhou, PX, or environmental protection" (Xiaotian 2016). Such methods discouraged many from further participating in offline protests.

The reaction by various government agencies towards their workers was also quite severe and has also had an impact on online discussions. For instance, many residents expressed dismay at the way educational institutions handled the situation. The Chengdu Department of Education issued a statement requiring: "all cadres and educational employees to conduct proper thought work; do not circulate, send, exaggerate or create any literature or pictures that touch upon smog" (Yang 2016). This in turn encouraged principals in their individual schools to take preventive measures. One elementary school principal even wrote the following message in a WeChat Group for parents of $2^{\text {nd }}$ graders:

Dear Parents, Good Morning! According to an urgent notice from upper levels of the government, we request that everyone do not believe or circulate rumors or participate in any illegal assemblies related to the recent "smog" related myths. We need to believe that the government will do their best to prevent and mitigate smog. Students and teachers at our school will be strictly prohibited from wearing facemasks during school. Every day from 3:30 to 4 p.m. the class leader will immediately report the situation of the day to their leading official. Thank you for everyone's understanding and cooperation. (Yang 2016)

The detailed message from this school principal appears to be extreme, and one Chengdu newspaper reported that no one in the WeChat group had actually received the message (Yang 2016). Thus, in this particular case it is very difficult to know if the principal's statement was an actual reaction to warnings issued by the government, or another example of protestors drawing on truthiness by creating false messages. Regardless, these reactions to the use of truthiness in an environmental protest show how counterproductive such strategies can be in an authoritarian context.

\section{Conclusion}

In this article we have demonstrated that during this period of severe air pollution in Chengdu in early December 2016, contentious politics over the Pengzhou refinery erupted into an online and offline protest. Bosco (2011: 147) noted a similar kind of social tension that built up in Hong Kong around widespread transmission of rumors of kidnapped children, when security anxieties may have been heightened by several factors, including high levels of air pollution in the city. In the case of Chengdu, tensions built up to such an extent that residents' critique of the contribution a refinery outside the city made to local air pollution drew upon 'truthiness' to support their protest. From the study we have presented, we can see that because the state obfuscated environmental information about the refinery and itself used truthiness to make truth claims about the safety of the refinery, this resulted in a mirrored reaction by the protesters who in turn used truthiness to support their protest. In Table 2, we can see specific examples of how both state actors and local residents used truthiness to present only selected facts or in some cases even false information that supported a given truth claim. When residents engaged in circulating this discourse they knew that it would fuel discontent and when faced with the fact that it was based on truthiness tried to argue that it was, nonetheless, representative of a 
popular sentiment. The examples in Table 2 also reminds us that the obfuscation of environmental information by state actors created the space for protestors to justify using truthiness.

\begin{tabular}{|c|c|c|c|c|}
\hline & Form & Action & Examples from State Actors & Examples from the Public \\
\hline \multirow{4}{*}{ Post-Truth } & \multirow{2}{*}{ Obfuscation } & $\begin{array}{l}\text { Preventing facts from being } \\
\text { researched }\end{array}$ & $\begin{array}{l}\text { Not allocating funds to support proper monitoring } \\
\text { of air pollutants emitted from the Pengzhou refinery }\end{array}$ & \\
\hline & & $\begin{array}{l}\text { Preventing others from knowing } \\
\text { about known facts }\end{array}$ & $\begin{array}{l}\text { Not publicizing the actual quantity of chemicals } \\
\text { produced at the Pengzhou refinery }\end{array}$ & \\
\hline & \multirow{2}{*}{ Truthiness } & $\begin{array}{l}\text { Presenting only selected facts } \\
\text { that support a given truth-claim }\end{array}$ & $\begin{array}{l}\text { Petroleum refineries producing PX, such as in } \\
\text { Pengzhou, are as safe as a zoo, and safer than } \\
\text { producing other chemicals. }\end{array}$ & $\begin{array}{l}\text { G20 proves Pengzhou refinery } \\
\text { produces more pollution than } \\
\text { automobiles }\end{array}$ \\
\hline & & $\begin{array}{l}\text { Presenting false information as } \\
\text { fact to support a given truth-claim }\end{array}$ & $\begin{array}{l}\text { CNPC claims that power fluctuations caused black } \\
\text { smoke to be emitted from the Pengzhou refinery }\end{array}$ & $\begin{array}{l}\text { Picture is from } 2012 \text { protest, not } \\
\text { related to Pengzhou refinery }\end{array}$ \\
\hline
\end{tabular}

Table 2: Examples of post-truth surrounding the Pengzhou refinery protest.

It is not our intention to justify the means used by either side, but rather to point out the hegemonic control of power by the state over truth claims related to environmental information. Protestors were faced with a kind of necropolitics (Mbembe 2003) that permeated both state-run media and the discourses of officials who reconstruct a sovereign environmentality that delineates who is and who is not being poisoned by environmental pollution. In reaction to protestors' use of truthiness, this necropolitics moves beyond discourse and into the realm of action, when residents are forced to present their ID to purchase a facemask to protect themselves from air pollution. We can then see that the inequities of social power have led protestors towards discursive strategies that manipulates a truth environmentality to support their cause.

Similar cases in the United States have documented how the use of false or "fake" information could even be beneficial to protestors in some contexts (Zhang et al. in press). However, our study clearly demonstrates that due to the hegemonic control of information by Chinese officials who support the refinery, it was not in the best interest of protestors in Chengdu to disseminate truthiness to support their cause. Once the government was able to demonstrate that environmental protestors disseminated falsehoods and half-truths, those promoting such a discourse were labeled as "anti-scientific." Within the particular context of some environmental controversies, being labeled "anti-science" will delegitimize a discourse and allow government officials to further embed their control over environmental information. For this reason, it may be in the best interests of those who wish to resist a sovereign environmentality controlled by an authoritarian regime to be cautious of certain forms of "alternative facts" when trying to strengthen their voice of protest. Because the discourse within our case study remains within the domain of environmental science, our argument is not meant to critique the political potential of ontologically unique interpretations of the environment (Sullivan 2017) found within indigenous social movements for undermining the hegemony of environmental science when it is used to prop up development projects. The two forms of truthiness we have documented do require that political ecologists continue to reflect upon how we are best suited to engage with Post-Truth politics.

Despite the awkward position Post-Truth places us in, Neimark et al. (2019) are absolutely correct that political ecologists still have an important role to play in terms of exposing the kinds of unequal power relations that are faced by environmental protestors. Even in authoritarian contexts like China, positive outcomes can develop through connections between scientists/experts and the protestors seen in other contentious environmental disputes in China, such as in the protests about solid waste incinerators in Guangdong and Beijing (Johnson 2013). Scientists can help ensure that protests focus on verifiable information, but political ecologists can also help ensure that the politics of those impacted by such projects are properly represented within the frame that scientific research provides. 
The case of the Pengzhou refinery also adds a Chinese urban political ecology dimension into this discussion. Scholars of, and in China have a great deal to contribute to the political ecology of contentious environmental politics. While Mertha briefly noted the use of truthiness to support protest over a hydropower project in Sichuan (2008: 92), this article has analyzed the Pengzhou refinery case to systematically explain how truthiness was used, and for what reason. Moreover, we have provided a more rigorous framework for the academic study of Post-Truth. While China has exhibited truthiness and the obfuscation of information for decades, in this article we have tried to show how the two concepts become interconnected as they emerge from the discourse and actions of both the state and local residents of Chengdu. Additionally, we see a close resemblance between truthiness and the obfuscation of information in China and the recent rise of similar discursive patterns in other parts of the world. Rather than work towards a kind of Chinese exceptionalism, we feel that both the framework and detailed case study presented here are an important contribution to the study of disputed truth-claims at the heart of environmental protests around the world.

\section{References}

Abrams, P. 1988. Notes on the difficulty of studying the state (1977). Journal of Historical Sociology 1(1): 5889.

Anderson, K. 2017. How America lost its mind. The Atlantic Sept. [Last Accessed April $4^{\text {th }}$ 2019] https://www.theatlantic.com/magazine/archive/2017/09/how-america-lost-itsmind/534231/

Andrews, S.Q. 2008. Inconsistencies in air quality metrics: 'blue sky' days and PM10 concentrations in Beijing. Environmental Research Letters 3(3): 034009.

Anonymous. 2014. Guangdong Maoming, 18 already arrested after PX project incident (广东茂名: PX 项目 事件已刑拘 18 人). People's Daily Online (人民网) April 3 ${ }^{\text {rd }}$, 2014. [Last Accessed Feb. 9 ${ }^{\text {th }}$ 2017] http://news.sina.com.cn/c/2014-04-03/162729858181.shtml.

Baba Zhongwan. 2016. Chengdu's cry (This just, I mean just, happened)成都的呐喊（刚刚, 就在刚刚发生 的 ). Baba Zhongwan (八八众玩) (Blog). December 12 $2^{\text {th }}$, 2016. [Last Accessed December 10 th $^{\text {th }}$ 2016] http://wsy.justravel.cn/app/index.php?i=2\&c=entry\&id=481\&uniacid=2\&do=detail\&m=amouse_articl e\&from=timeline\&wxref=mp.weixin.qq.com\#wechat_redirect.

Banchoff, T. 2005. Path dependence and value-driven issues: the comparative politics of stem cell research. World Politics 57(2): 200-230.

Beeson, M. 2010. The coming of environmental authoritarianism. Environmental Politics 19(2): 276-294.

Bestwise. 2016. We are a relay, please let us breathe. (我们接力, 请让我们呼吸). Peizhi Tech (倍智科技) (Blog). December $\quad 9^{\text {th }}, \quad 2016 . \quad$ [Last $\quad$ Accessed $\quad$ Feb. $14^{\text {th }}$ 2017] http://mp.weixin.qq.com/s/Fmef6JmPrsmfMUmsQyv4DA.

Bosco, J. 2011. The Hong Kong Ocean Park kidnapping rumor. Ethnology 50(2): 135-151.

Brombal, D. 2017. Accuracy of environmental monitoring in China: exploring the influence of institutional, political and ideological factors. Sustainability 9(3): 324.

Cai, Yongshun. 2010. Collective resistance in China: why popular protests succeed or fail. Stanford: Stanford University Press.

Carvalho, A. 2007. Ideological cultures and media discourses on scientific knowledge: re-reading news on climate change. Public Understanding of Science 16(2): 223-243.

Cavanagh, C.J. 2018. Political ecologies of biopower: diversity, debates, and new frontiers of inquiry. Journal of Political Ecology 25: 402-425.

Chengdu Environmental Protection Agency (CDEPA). 2016. There are fewer blue sky days, other than taking trash, do you dare to drive one day less? Can you not spread rumor, huh? (天蓝了少许 除了吐槽你敢 少开一天车么? 不传谣么?) Chengdu Environmental Protection Agency: Chengdu, Sichuan. December $5^{\text {th }}, 2016$. [Last $A c c e s s e d \quad F e b .1^{\text {th }}$ 2017] http://mp.weixin.qq.com/s/ekMeP4ugvAP9Q_rXFXTzQ 
Cody, E. 2007. Text messages giving voice to Chinese. Washington Post. June 28 ${ }^{\text {th }}$. [Last Accessed Nov. 13, 2018] http://www.washingtonpost.com/wp-dyn/content/article/2007/06/27/AR2007062702962.html

Davies, T. 2018. Toxic space and time: slow violence, necropolitics, and petrochemical pollution. Annals of the American Association of Geographers 108(6): 1-17.

Deng, Y. and G. Yang. 2013. Pollution and protest in China: environmental mobilization in context. China Quarterly 214: 321-336.

Ding, N. 2016. Head of Chengdu EPA takes group to conduct snap inspections of key monitored enterprises (成都市环保局长带队突击检查重点监控企业). Sichuan Online (四川在线). December 11 $1^{\text {th }}, 2016$. [Last Accessed Feb. 14 ${ }^{\text {th }}$ 2017] http://sichuan.scol.com.cn/fffy/201612/55762711.html.

Distelhorst, G. 2017. The power of empty promises quasi-democratic institutions and activism in China. Comparative Political Studies 50(4): 464-498.

Duranti, A. 2015. The anthropology of intentions language in a world of others. Cambridge: Cambridge University Press.

Fletcher, R. 2017. Environmentality unbound: multiple governmentalities in environmental politics. Geoforum 85: 311-315.

Funtowicz, S.O. and J.R. Ravetz. 1990. Uncertainty and quality in science for policy. Dordrecht: Kluwer Academic.

Gary, J.H., G.E. Handwerk and M.J. Kaiser. 2007. Petroleum refining: technology and economics. Boca Raton: CRC Press.

Guha, R. 1983. Elementary aspects of peasant insurgency in colonial India. Oxofrd: Oxford University Press.

Gu, H. 2016. NIMBYism in China: issues and prospects of public participation in facility siting. Land Use Policy 52: 527-534.

Harper, K. 2005. "Wild capitalism" and "ecocolonialism": a tale of two rivers. American Anthropologist 107(2): 221-233.

Heynen, N., 2014. Urban political ecology I: the urban century. Progress in Human Geography 38(4): 598-604.

Hurst, W. 2017. Treating what ails the study of Chinese politics. Made in China 2(3): 55-59.

Ji, P. 2016. Emotional criticism as public engagement: how weibo users discuss 'Peking University statues wear face-masks'. Telematics and Informatics 33(2): 514-524.

Johnson, T. 2016. Regulatory dynamism of environmental mobilization in urban China. Regulation and Governance 10(1): 14-28.

Johnson, T. 2013. The health factor in anti-waste incinerator campaigns in Beijing and Guangzhou. The China Quarterly 214: 356-375.

Keyes, R. 2004. The post-truth era: dishonesty and deception in contemporary life. New York: St. Martin's Press.

King, G., J. Pan and M.E. Roberts. 2013. How censorship in China allows government criticism but silences collective expression. American Political Science Review 107(2): 326-343.

Language Log. 2005. Truthiness or trustiness? Language Log (blog). October $26^{\text {th }}$, 2005. [Last Accessed Feb. $14^{\text {th }}$ 2017] http://itre.cis.upenn.edu/ myl/languagelog/archives/002586.html.

Liao, M. 2016. Pengzhou AQI levels from January to October ranked $8^{\text {th }}$ in Chengdu (1-10 月彭州空气质量 综合指数 排名成都市第八) Netease (网易). December $3^{\text {rd }}$, 2016. [Last Accessed Feb. 14 ${ }^{\text {th }}$ 2017] http://help.3g.163.com/16/1203/08/C7BKK4UN00964J4O.html.

Little, P.C. 2017. On the micropolitics and edges of survival in a technocapital sacrifice zone. Capitalism Nature Socialism 28(4): 62-77.

Liu, J. 2016. Digital media, cycle of contention, and sustainability of environmental activism: the case of antiPX protests in China. Mass Communication and Society 19(5): 604-625.

Liu, Y., Y. Li, B. Xi and J. Koppenjan. 2016. A governance network perspective on environmental conflicts in China: findings from the Dalian paraxylene conflict. Policy Studies 37(4): 314-331. 
Liu, Y. 2014. Media reveals the truth about the petroleum refinery in Pengzhou, Sichuan: It is difficult to stop a 30 billion yuan investment due to pollution concerns (媒体揭四川彭州石化真相：投资 300 多亿因 污染骑虎难下), Oriental Outlook (瞭望东方周刊). March 30th, 2014. [Last Accessed March 30th 2014] http://news.ifeng.com/mainland/detail_2014_03/30/35283005_0.shtml.

Lora-Wainwright, A. 2013. Fighting for breath: living morally and dying of cancer in a Chinese village. Honolulu: University of Hawai'i Press.

Lora-Wainwright, A. 2017. Resigned activism: living with pollution in rural China. Cambridge: MIT Press.

Lorentzen, P. 2017. Designing contentious politics in post-1989 China. Modern China 43(5): 1-35.

Matulis, B.S. and J.R. Moyer. 2018. Hijacking the narrative: The First World Forum on natural capital, \#natcap13, and radical dissent. Antipode 50 (2): 384-406.

Mbembé, J.A. and L. Meintjes. 2003. Necropolitics. Public Culture 15(1): 11-40.

Mertha, A. 2008. China's water warriors: citizen action and policy change. Ithaca: Cornell University Press.

Mitchell, T. 2011. Carbon democracy: political power in the age of oil. London: Verso.

Munger, M.C. 2008. Blogging and political information: truth or truthiness? Public Choice 134(1-2): 125-138.

Neimark, B., J. Childs, A. Nightingale, C. J. Cavanagh, S. Sullivan, T.R. Benjaminsen, S.P.J. Batterbury, S. Koot and W. Harcourt. 2019. Speaking power to 'post-truth': critical political ecology and the new authoritarianism Annals of the American Association of Geographers 109(2): 613-623. researchgate

Nie, Z. 2016. Chengdu, please don't force me to leave (成都, 请不要逼我离开). Nie Zuoping (blog) December $6^{\text {th }}$, 2016. [Last Accessed Feb. 14 ${ }^{\text {th }}$, 2017] http://chuansong.me/n/1251218051130.

Nisbet, M. 2016. Climate denial's Trump card. New Scientist 230(3077): 18-19.

O'Brien, K.J. and L. Li. 2006. Rightful resistance in rural China. Cambridge: Cambridge University Press.

Pieke, F.N. 2004. Contours of an anthropology of the Chinese state: political structure, agency and economic development in rural China. Journal of the Royal Anthropological Institute 10(3): 517-538.

Rival, L. 2014. Encountering nature through fieldwork: expert knowledge, modes of reasoning, and local creativity. Journal of the Royal Anthropological Institute 20(2): 218-236.

Robbins, P. 2011. Political ecology: a critical introduction. Oxford: Blackwell.

Schmalzer, S. 2007. On the appropriate use of rose-colored glasses: reflections on science in socialist China. Isis 98(3): 571-583.

Shi, P. 2016. Chengdu has become 'dust city', but it is a microcosm of the air pollution in China's central and western regions (成都变尘都, 不过是中西部空气污染的缩影). Greenpeace Movement (绿色和平行 动派) (Blog) December $9^{\text {th }}$, 2016. [Last Accessed Feb. 10 ${ }^{\text {th }}$ 2017] http://mp.weixin.qq.com/s/ 5 4CjYSpfQ4yzAbJMWfg

Shu, J. 2012. Strategic environmental assessment of key industry development in the Chengdu-Chongqing economic zone (成渝经济区重点产业发展战略环境评价研究). Beijing: China Environment Press (北 京: 中国环境出版社).

Simonelli, J., 2014. Home rule and natural gas development in New York: civil fracking rights. Journal of Political Ecology 21(1): 258-278.

Sohu. 2016. Chengdu Tianfu Square begins to prohibit large commercial activities and illegal gatherings (成都 天府广场开始禁止大型商业活动和非法集会) Sohu.com December 10 $0^{\text {th }}, 2016$. [Last Accessed Feb. $14^{\text {th }}$

2017]

https://m.sohu.com/n/223421455/?from=timeline\& once $=000022$ shareback wechat flow

Sonnenfeld, D. A., and P. L. Taylor. 2018. Liberalism, illiberalism, and the environment. Society and Natural Resources 31(5): 515-524.

Sparks, S. 2006. A long history: civil society, pollution and the Wentworth oil refinery. Centre for Civil Society Research Report 45: 167-193.

Steinhardt, H. C., and F. Wu. 2016. In the name of the public: environmental protest and the changing landscape of popular contention in China. The China Journal 75(1): 61-82. 
Stern, R.E. and O'brien, K.J., 2012. Politics at the boundary: mixed signals and the Chinese state. Modern China 38(2): 174-198.

Sullivan, S. 2017. What's ontology got to do with it? On nature and knowledge in a political ecology of the 'green economy'. Journal of Political Ecology 24(1):.217-242.

Sun, Xiaoyi, Ronggui Huang, and Ngai-Ming Yip. 2017. Dynamic political opportunities and environmental forces linking up: a case study of anti-PX contention in Kunming. Journal of Contemporary China 26(106): 1-13.

Tang, F. 2016. Planned protest against smog in southwest China shut down before it begins South China Morning Post. December 10 10 2016. [Last Accessed Oct. 30 ${ }^{\text {th }}$ 2017] http://www.scmp.com/news/china/article/2053556/planned-protest-against-smog-southwest-chinashut-down-it-begins.

Tilt, B. 2010. The struggle for sustainability in rural China: Environmental values and civil society. New York: Columbia University Press.

Turner, B.L. and P. Robbins. 2008. Land-change science and political ecology: Similarities, differences, and implications for sustainability science. Annual Review of Environment and Resources 33: 295-316.

Vesalon, L. and Creţan, R., 2015. 'We are not the Wild West': anti-fracking protests in Romania. Environmental Politics 24(2): 288-307.

Wangong Shuweng. 2016. 丧钟为谁而鸣: 今日尘堵大晴天，云开雾散皬不散 Wangong Shuweng (Blog) December $3^{\text {rd }}$, 2016. [Last Accessed Dec. $5^{\text {th }}$ 2016] https://a.meipian.cn/9qq9t4k?from=groupmessage

Wang, S. 2008. Changing models of China's policy agenda setting. Modern China 34(1): 56-87.

Wang, Y. 2016. Chengdu people within the smog (雾䨪天里的成都人). You're a dark pond in the deep of night (你在深 夜 是个碧池 ) (Blog). December 5 $5^{\text {th }}$ ，2016. [Last Accessed Feb. 9 ${ }^{\text {th }}$ 2017] http://mp.weixin.qq.com/s/rfvd3bxZ5jj_8udbZvLGbA.

Wong, E. 2008. In China city, protesters see pollution risk of new plant. New York Times May ${ }^{\text {th }}$. [Last Accessed Feb. 10 ${ }^{\text {th }}$ 2017] http://www.nytimes.com/2008/05/06/world/asia/06china.html

Xiang, Y. 2017. Head of Sichuan EPA: 24 hour special monitoring of Pengzhou refinery, Newly added 21 drones for aerial monitoring (四川省环保厅厅长: 24 小时专门监测彭州石化 新增 21 架无人机空 中监测 ). Takung Pao Online (大公网) July 23 ${ }^{\text {rd }}$, 2017. [Last Accessed April 9 $9^{\text {th }}$ 2019] http://china.takungpao.com/sichuan/2017-07/3475907.html

Xiaotian. 2016. December $12^{\text {th }}$, smog, Chengdu is without a facemask (12 月 12 日，霧，成都无口罩). NGOCN.com (blog). December $12^{\text {th }}$, 2016. [Last $\quad$ Accessed $\quad$ Feb. 14 $4^{\text {th }}$ 2017] http://mp.weixin.qq.com/s/JCGmC5Tc9MVDlXnD5WbodQ.

Yang, G. 2010. Brokering environment and health in China: issue entrepreneurs of the public sphere. Journal of Contemporary China 19(63): 101-118.

Yang, G. 2005. Environmental NGOs and institutional dynamics in China. China Quarterly 181: 46-66.

Yeh, E.T. 2009. Greening western China: a critical view. Geoforum 40(5): 884-894.

Yeh, E.T. 2015. Political ecology in and of China. In Bryant, R.L. (ed.). The international handbook of political ecology. London: Edward Elgar. Pp. 619-632.

Yin, N. 2013. Chengdu takes a stand on the Pengzhou refinery project: actively facing the issue is a kind of progress (成都表态彭州石化项目:主动面对就是一种进步). China Online News (中国网新闻). April 30th, 2013. [Last Accessed $\quad$ Feb. http://forum.china.com.cn/forum.php?mod=viewthread\&action=printable\&tid=3147394

Yu, S. 2016. Chengdu residents gathered at Tianfu Square because of smog? official response: rumor (成都市 民因雾䨪聚集天府广场？官方回应:谣言) China News Online (中国新闻网) [Last Accessed Feb. 14th 2017] http://www.chinanews.com/sh/2016/12-10/8090000.shtml.

Zhang, M. 2014. Cao Xianghong: 'PX-phobia' is the greatest challenge for the development of the industry (曹 湘洪:PX 恐懼症是產業發展的最大挑戰 ). China Energy Post (能源網-中國能源報 ). April 10th, 2014. [Last Accessed: April 21st, 2014] http://www.cnenergy.org/yw/201404/t20140410_301331.html. 
Zhang, S., T. Yuanyuan T., Bo Z. and Shenliang C. In Press. Stand with \#StandingRock: Towards an epistemological shift in understanding geospatial big data during the post-truth era. Annals of the Association of American Geographers.

Zhu, Z. 2017. Backfired government action and the spillover effect of contention: a case study of the anti-PX protests in Maoming, China. Journal of Contemporary China 26(106): 1-15. 